\title{
COISAS DO OUTRO MUNDO: UMA LEITURA DO CONTO “O ESPELHO”, DE GASTÃO CRULS
}

\author{
Dayna Suzelli Lins da Silva* \\ Sérgio da Fonseca Amaral*
}

\begin{abstract}
RESUM0: Os signos das coisas são alusões a seres imprescindíveis e secundários do mundo que, com elas, se torna humano. Em literatura, por exemplo, demarcam ou tempo, ou lugar, ou cultura, ou ambiente ou ação. Logo, o signo do objeto intensifica o referente em sua ação cotidiana. Referente e referido se entreolham. Nessa complexa relação, há um artefato predileto como signo de ruptura entre a realidade e a irrealidade: trata-se do espelho. Personagens errantes se defrontam com imagens fantasmáticas de outros mundos possíveis. Com este trabalho, propomos verificar no conto "0 espelho", de Gastão Cruls, a atuação dessa coisa na construção de uma história fantástica e de seu efeito na ruptura da realidade ordinária.
\end{abstract}

PALAVRAS-CHAVE: Literatura brasileira; Gastão Cruls; “0 Espelho”; Coisas; Fantástico.

\section{THINGS OF THE OTHER WORLD: AN INTERPRETATION OF GASTÃO CRULS'S SHORT STORY 0 ESPELHO}

ABSTRACT: The signs of things are allusions to indispensible and secondary beings of the world which becomes human through them. In literature they mark time, place, culture, milieu, action. The sign of the object intensifies the referent in its daily activity. Referent and referred look at one another. Within this complex relationship, there is an artifact as a sign of rupture between reality and non-reality: the mirror. Wandering characters face phantasmagoric images of other possible worlds. Other worldly things in Gastão Cruls's short story 0 espelho are analyzed within the construction of fantastic history and its effect on the rupture of normal reality.

KEYWORDS: Brazilian literature; Gastão Cruls; 0 Espelho; Non-worldly thing; Fantastic.

\section{INTRODUÇÃO}

Entre as mais abalizadas investigações sobre o fantástico, insólito e correlatos não é muito comum 0 interesse em investigar a presença e a importância das coisas no intercâmbio com os agentes humanos para a constituição do inexplicável, do insólito, do medo, do horror, do pânico ou simplesmente da interface entre 0 natural e 0 sobrenatural. Até onde sabemos, todas as análises críticas ou as considerações teóricas são calcadas ou nas personagens, que representam os humanos - ou seja, humanos virtuais -, ou nos sobre-humanos e parahumanos, mas não as "personagens" que remetem às coisas que regularmente são partes fundamentais das narrativas que envolvem o mundo fantástico (entendido aqui em um sentido lato, não no restrito todoroviano). Não pode haver contos de fadas sem a varinha de condão, ou falar de bruxas sem o caldeirão e de vassouras voadoras, de gnomos sem os gorros e a indumentária verde etc. Coisas tão evidentes em qualquer história, sistematicamente passam desapercebidas pelas teorizações e críticas, levando em conta apenas o agente humano como único causador de uma dada situação extraordinária, esquecendo-se que sem o portal não se pode atravessar para

\footnotetext{
* Graduada em Letras - Língua portuguesa e suas literaturas pela Universidade Federal do Espírito Santo (UFES), Brasil.

** Doutor pela Universidade Federal do Rio de Janeiro (UFRJ) e Pós-Doutor pela Pontifícia Universidade Católica do Rio de Janeiro (PUC-RJ). Docente Titular de Literatura Brasileira e Estudos Literários no Departamento de Línguas e Letras da Universidade Federal do Espírito Santo (UFES), Brasil. E-mail: sergio.amaral@ufes.br
} 
outro tempo-espaço. Para desviar um pouco dessa linha que já rendeu tantos trabalhos imprescindíveis para pensarmos as narrativas fantásticas (sempre entendendo o termo num sentido lato), intentaremos aqui focar 0 estudo a partir de um dado objeto como fundamental para se construir determinadas narrativas de cunho extraordinário. Chamamos esse tipo de abordagem de "a vida ficcional das coisas". Tal objeto a ser colocado em primeiro plano para analisarmos algumas narrativas será 0 espelho.

\section{O ESPELHO E SUAS IMAGENS}

A substância dos espelhos é gerar imagens, por isso incitam tantos imaginários, criando expectativas no sujeito que as vê: desejadas (pensemos em Narciso), ou indesejadas (pensemos na madrasta da Branca de Neve). Imagens que se tornaram, elas próprias, no pensamento místico e laico, da tradição ocidental, em força de adoração, de pensamento, de êxtase e terror, e de controle político, ao ser manipulada por aparelhos sofisticados em sua captação. Desse modo, não é de se espantar que as narrativas viriam a explorar esse seu outro de forma a poder criar mais uma reprodução imagética, por meio da linguagem escrita (cuidamos aqui de literatura), para confrontar 0 outro do leitor diante daquilo que seu imaginário apagou como possibilidade de existir. É disso que trata a literatura fantástica, assim como o maravilhoso, o realismo mágico, 0 insólito e outras ramificações.

Por meio das imagens especulares, que reproduz os seres ensejando o Duplo, a literatura fantástica, no sentido estrito - aquela que instaura 0 inexplicável na realidade conhecida, seja pela incapacidade de se tomar uma decisão se é natural ou sobrenatural, seja pela irrupção do extraordinário no seio do ordinário - (ROAS, 2014, p. 42-3), cria situações que colocam 0 sujeito diante de seus limites psíquicos, por vezes físicos, sentimento de impotência ou de perturbação diante de algo indizível ou inexplicável, insegurança e dúvida metafísica. Por isso, a literatura fantástica assume definitivamente um compromisso com a verossimilhança e o verossímil, pois depende deles para sugerir 0 efeito de ruptura entre uma realidade e outra e o insólito se manifestar. Ou, como bem nos diz Roas,

A literatura fantástica é aquela que
oferece uma temática tendente a pôr
em dúvida nossa percepção do real.
Portanto, para que a ruptura antes
descrita se produza é necessário
que o texto apresente um mundo 0
mais real possível que sirva de termo
de comparação com o fenômeno
sobrenatural, isto é, que torne evidente
0 choque que supõe a irrupção de tal
fenômeno em uma realidade cotidiana.
0 realismo se converte assim em uma
necessidade estrutural de todo texto
fantástico. (lbidem, p. 51 ). Contudo,

[...] Diferentemente de um texto realista, quando nos deparamos com uma narrativa fantástica essa exigência de verossimilhança é dupla, uma vez que devemos aceitar - e acreditar em - algo que o próprio narrador reconhece, ou estabelece, como impossível. E isso traduz em uma evidente vontade realista dos narradores fantásticos, que tentam fixar 0 narrador na realidade empírica de um modo mais explicito que os realistas. (lbidem, p. 51-2).

0 fantástico não seria concebido como tal se tudo fosse possível no mundo ordinário (anulando, assim, o extraordinário). A estupefação está na possibilidade aberta pela introdução de um "descontínuo" no meio do ordinário, "realizando" algo considerado impossível por esse padrão de existência. Contudo, como bem ressalta Roas, o possível e 0 impossível dependem também de um olhar histórico cultural sobre os acontecimentos, além, evidentemente do grau e tipo de crença que grupos ou comunidades abraçam em seus respectivos tempo e sociedade 3 . Assim, por exemplo, para uma época que desconhece

\footnotetext{
Embora Roas não aborde explicitamente as nuances decorrentes do raciocínio desenvolvido, pois, detém-se mais na historicidade do próprio gênero fantástico e das condições socioculturais que envolveram seu aparecimento - ruptura com a visão de mundo medieval pelo lluminismo, o romantismo e a afirmação do Eu, basicamente - é plenamente cabível alargar o entendimento de possibilidade de um fenômeno fantástico do modo como estamos afirmando acima. Conferir (ROAS, op. cit., p. 47-50).
} 
as modernas câmeras e celulares, ter notícias de alguém que está longe por meio de uma coisa capaz de captar e trazer sua imagem, ou voz, para a presença de quem a possui, essa coisa é considerada mágica. Ou voar montado num tapete é mágico, pois, primeiro, voar seria para os pássaros, e, segundo, uma pessoa humana dotada de uma dádiva dessas apenas seria possível por um elemento mágico ou divino. Os valores (éticos ou morais) que circulam socialmente em cada tempo ou cultura também são passíveis de gerar situações insólitas, como veremos mais adiante num conto de Gastão Cruls.

Nesse âmbito, verificamos que o nosso objeto de estudo costuma funcionar como portal para o insólito de forma que, se retirado das diversas narrativas em que aparece, não poderiam ser substituídos por quaisquer outras coisas sem que a narrativa ficasse comprometida. Para efeito de definição, vale ressaltar que espelho, aqui, é entendido como qualquer superfície que reflete, retrata ou representa as imagens que 0 defrontam, ou confrontam.

As coisas são signos tanto na vida real, quanto na ficcional. A diferença fundamental, porém, é que na vida ficcional tornam-se coisas não por ganharem vida, já que no mundo real também a têm, mas porque sob a condição ficcional essa vida é plenamente revelada, pois numa estrutura narrativa todos os elementos componentes de signos interagem para produzir aquele efeito desejado pelo seu desenvolvimento em direção ao desfecho de uma ação. A coisa-signo não apenas empresta uma qualidade à personagem, mas passa a exercer uma ação conjunta com ela, como, por exemplo: homem-arma; mulher-varinha de condão, criando uma composição que únicos atingem um determinado fim ${ }^{4}$. No entanto, a valia do espelho em literatura vai além das situações como a da personagem que conta o tempo por meio de uma ampulheta, já que isso automaticamente nos remeteria a uma determinada época. Sendo a ampulheta de ouro, isso nos informaria sobre a posição social da personagem. Tudo isso, como se vê, mistura-se ao corpo da narrativa, formando uma estrutura única, mas o espelho duplica e desvela a própria natureza da ficção.

Segundo Umberto Eco, o espelho é incapaz de produzir signos, pois a imagem especular só se faz presente quando um referente está também presente. 0s signos existem para representar coisas não presentes. A imagem no espelho é produzida na presença de um objeto e não pode ser reproduzida em sua ausência (EC0, 1989, p. 25-6). A imagem especular não sendo signo no mundo real, seguindo de perto a argumentação de Umberto Eco, e sendo irreal (pois cria ilusão de fundo quando tudo está na superfície) torna-se um duplo da própria literatura.

Ainda segundo Umberto Eco, os espelhos são próteses que ampliam 0 alcance dos sentidos. 0 olho não consegue por si só enxergar a face na qual está inserido sem estender 0 alcance da visão por uma suplementação de suas órbitas, que apenas pode ser efetivada por uma superfície espelhada.

\footnotetext{
Tim Ingold, antropólogo escocês, seguindo de perto as meditações de Heidegger acerca da coisa, polemiza com outros antropólogos sobre a noção de agenciamento (como Bruno Latour e Alfred Gell, por exemplo), que não deixa de horizontalizar a relação homem-objeto, mas que ainda permanece enrijecida pelo conceito objeto. Efetivamente Heidegger, no artigo "A Coisa" (2012, p. 143-164), distingue nitidamente uma coisa da outra (e mostra que a jarra não é apenas um recipiente, mas um encontro e doação). Num artigo, Ingold (2012) discute e trabalha a ideia de coisa em lugar da de objeto por aquela possibilitar de pensar as relações no mundo, ou a mundanizaçao do mundo humano, seguindo de perto Heidegger, como entrelaçamentos de várias ordens (terra, céu, água, ar, mortais, animais, vegetais e coisas) que, em suma, significa a própria vida. Objeto, ao contrário, é a nomeação preponderante da modernidade para as coisas, o que indica o seu sequestro e apropriação para fins utilitários. 0 corolário disso é 0 distanciamento, isolamento e arrogância do humano diante do mundo habitado por inextricáveis seres, mas cortejados, caçados e descartados como simples suplementos, insumos ou enfeites. Pensamos ser esse 0 teor do texto de Heidegger e a proposta de Ingold: "Uma sala sem objetos, poderíamos concluir, é praticamente inabitável. Para que ela esteja pronta para qualquer atividade, ela deve ser mobiliada" (INGOLD, 2012, p. 27-8). Descontando a escorregadela nos objetos, como se vê uma casa é muito mais que um espaço onde nos comprazemos conosco mesmos. Por isso pensamos, a partir de todas essas meditações, que 0 discurso ficcional apresenta ser o lugar mais receptivo para que coisas voltem a ser as coisas, escapando a sua objetualização, independente da intenção do texto para com elas. Desse modo, o fantástico, por sua própria natureza, faz disso quase que uma necessidade para 0 andamento do enredo. E o espelho é uma peça fundamental de inesgotáveis narrativas, demonstrando que o enovelamento da vida se faz entre mortais, coisas, animais e tudo o mais que se encontra ou confronta entre si.
} 
Uma prótese, no sentido exato, é um aparelho que substitui um órgão que falta (membro artificial, dentadura etc.), mas, no sentido lato, é todo aparelho que aumenta o raio de ação de um órgão. Desse modo, podem ser consideradas próteses os megafones, as cornetas acústicas, as pernas de pau, óculos, as lentes de aumento os periscópios. As próteses estendem a ação de um órgão e podem ter funções tais como a de apurar 0 alcance do olho e aproximar objetos tanto macros como micros (como os vários tipos de lente), ou a de maximizar a potência, força ou delicadeza de uma ação (gruas ou pinças, que permitem estender 0 raio de preensão dos dedos, mas eliminam as sensações térmicas e táteis). Assim sendo, o espelho também age como uma prótese, pois permite que se obtenha 0 estímulo visual onde 0 olho não pode alcançar (Ibidem, p. 17-19).

Em narrativas literárias a coisa espelho necessariamente não segue seu correlato estudado por Eco, porquanto todo espelho, em literatura, tem sua imagem congelada, pois o que ali se passa é eternizado por meio dos significantes linguísticos da obra ficcional. Especialmente quando há uma licença para o fantástico, porque tal objeto, na ficção, além de produzir signos, permite que eles se bifurquem $\mathrm{e}$ deslizem entre mundos distintos pelo plano aquém e além da imagem especular encenada, cuja cena recria, desloca, ou repropõe existências ao desviá-las daquilo que temos como realidade. Estaria, portanto, o espelho do conto de Cruls a desobedecer a regra de Eco e a produzir signos disfarçadamente por entre os traços de um homem, mostrando o rosto de Outros não presentes. Semelhante fato só é perfeitamente realizável quando se trata de ficção, e mais ainda quando é fantástica, uma vez que, da forma como é estruturado o conto, é possível que se trate de loucura, porém a narrativa deixa aberta a possibilidade de que aqueles homens habitavam - ou eram prisioneiros -, de fato, o outro lado do espelho. É nesse acontecimento insólito, nessa hesitação entre uma coisa e outra que a narrativa de Cruls transita. Desse modo, podemos deduzir que 0 espelho age ali não como uma prótese, pois não estende 0 olhar da personagem para ver ângulos inalcançáveis de algo não visível ao seu olho, mas, ao contrário, exibia o isso invisível a sua consciência capturada pelo espelho. Como um poço dos desejos, realiza e revela as faces verdadeiras do narrador e da esposa, escondidas sob 0 véu da respeitabilidade matrimonial $\mathrm{e}$, por extensão, de todo o universo convencionado sobre sexo, desejo, erotismo e casamento no mundo social burguês. Nesse sentido, é perfeitamente plausível aceitar que aqueles homens evadiam-se para usufruir os prazeres da cama e estavam, de fato, resguardados no fundo, ou nas laterais, encobertos pela moldura, do espelho.

Por isso há tantos espelhos nas narrativas e artes de qualquer espécie. Ele manifesta-se como algo misterioso para o olhar humano e, desse modo, alguns tipos de ficção recorrem a ele para comunicarse com outro lado que, apenas atravessando sua superfície ilusória, podemos ter acesso; e isso só a ficção e o fantástico podem fazer. Cabe aqui inferir que, talvez, essa importância do espelho no fantástico seja herança das narrativas populares acerca desse objeto. Por exemplo, a ideia de que o espelho mostra o que estaria além do físico: a alma humana. Assim acontece em diversas narrativas acerca do outro desconhecido. De formal geral, na linguagem do fantástico a imagem especular está ligada, de alguma forma, ao universo pessoal de quem a defronta... ou a confronta.

Outros portais para um mundo mágico, de êxtase ou terror, também existem, como 0 guardaroupa de Nárnia, ou portas que abrem para um além, porém, defendemos que nosso objeto de estudo, a coisa espelho, sendo adentrado ou apenas defrontado, é um portal para o mais recôndito interior de uma personagem. Esse portal se coloca como vaso comunicante entre dois planos: 0 eu e 0 outro da personagem que conflitam entre si e são sensíveis ao outro mundo possível, para o bem ou para o mal. 


\section{A SEMIOSE DAS MOLDURAS}

A moldura direciona o olhar e influencia na recepção de tudo aquilo o que por ela é circundado. Assim acontece com pinturas em tela e [...] com os espelhos. Com os espelhos ficcionais - como já dito, pontes para 0 insólito -, a moldura pode ser um recurso fundamental para a interpretação. No entanto, leve-se em consideração que a moldura é a parte não espelho do espelho que espelha a história do espelho o qual encerra. Desse modo, tal coisa-signo em literatura apresenta uma função semiósica que complementa a atitude sorrateira do espelho. A moldura cerca e limita duas dimensões do espelho: a altura e a largura, menos a profundidade; é a única coisa potencialmente isenta de uma imagem especular, pois não entra em seu raio de reflexão, mas, concomitantemente, diz tudo sobre ele, como o tempo e o lugar de que veio.

Vejamos isso no aludido conto de Gastão ruls ${ }^{5}$, "0 espelho". Esse objeto tem em sua moldura figuras de significâncias ao mesmo tempo libidinosas e luxuosas, "[...] três folhas enquadradas em bronze, eram ainda de bronze as figurinhas de sátiros e ninfas que, destacando-se entre festonadas de verdura, formavam a ornamentação do soco, onde, sob um tampo de ônix verde, havia três gavetinhas de segredo" (CRULS, 1951, p. 339).

A estética e as dimensões do espelho parecem discrepar da mobília e do espaço doméstico, bem como da conduta familiar socialmente construída segundo o código moral cristão vigente à época. Inicialmente, é essa moralidade junto ao pensamento religioso que faz com que o narrador-personagem tenha uma postura defensiva quanto à presença do objeto, adquirido por sua esposa em um leilão ofertado por uma ex-meretriz. Consumado 0 fracasso de sua resistência, 0 marido debruça o olhar de veneração e espanto sobre 0 móvel e qualifica-se como inapto a definir o estilo estético da rica obra de arte e chega a deduzir que tenha sido feita sob encomenda e não pertença, na verdade, a nenhum padrão estético de época alguma, mas fruto da excentricidade e luxúria de alguém. Apesar de não se poder afirmar, a presença de figuras da mitologia grega,

\footnotetext{
Para conhecer um pouco do autor do conto estudado, segue abaixo uma pequena biobibliografia de Gastão Cruls, citada da dissertação de Claudio Silveira Maia, defendida na Universidade Estadual Paulista Júlio de Mesquita: Onde se fecham as aspas? "Em 04 de maio de 1888, nasceu Gastão Luis Cruls, filho de Luís Cruls, cientista belga, matemático e astrônomo, trabalhando no Brasil a convite do imperador D. Pedro II, e de dona Maria de Oliveira, mulher de vida simples, humilde e recatada. Conforme Raimundo de Meneses (1956), na cidade do Rio de Janeiro, àquela época Distrito Federal, Gastão Cruls iniciou-se nos estudos às vias do Colégio Ruch, no antigo morro do Castelo, de onde se transferiu, ao tempo do Ginásio, para Petrópolis. Parece que gostava de mudanças: tornou a transferir-se primeiro para o São Vicente e depois para o Colégio Pedro II. Desejando atender aos desejos do pai, diplomou-se médico em 1910. Ainda na Universidade assistiu o professor Miguel Couto, especializou-se em Medicina Sanitária e, exercendo função no Serviço de Saneamento Rural, participou da expedição às Guianas com 0 marechal Cândido Mariano Rondon. Ao voltar, dedicou-se à literatura e tomou posto de bibliotecário da Universidade do Distrito Federal, sendo nomeado chefe dos serviços de Biblioteca da Secretaria da Educação, responsabilidade que desempenhou até aposentar-se. Todavia, segundo lemos da crítica, é a relação do médico com o paciente o conteúdo material para as suas primeiras estórias. Segundo Meneses (1956), o interesse pelo veio literário fê-lo aproximar-se de escritores como Antônio Torres, Gilberto Amado, Monteiro Lobato e Miguel Osório de Almeida. Particularmente do primeiro, sobre quem, depois de sua morte, lançou Antônio Torres e seus amigos (1950), privou preciosa e frutífera amizade, como nos revelam algumas cartas de Torres a Gastão Cruls, compendiadas no "Volume 2". Por esse tempo, de primeiros contatos com a literatura, no ano de 1917, Gastão Cruls, sob o pseudônimo de Sergio Spinola, publicou os seus primeiros contos na Revista do Brasil, então dirigida por Monteiro Lobato, e, depois, com outros, agora sob o seu próprio nome, republicou-0s no volume Coivara (1920). Conforme nota da editora à edição de Quatro romances (1958), Cruls viveu os anos de 1921 e 1922 na Paraíba do Norte, como membro da Comissão de Saneamento Rural, chefiada por Acácio Pires. Por essa ocasião, oportunou-lhe observar os cenários nordestinos incluídos em seu segundo livro de contos Ao embalo da rede (1923). Logo depois, destacou-se como o primeiro grande intérprete da Amazônia: antes de conhecê-la publicou A Amazônia misteriosa (1925), em que a descreve por nuanças reais como se nela houvesse estado. Mais tarde, após visitá-la, lançou A Amazônia que eu vi (1930) e, post scriptum, Hiléia amazônica (1944). Entre 1931 e 1938, dedica-se quase que exclusivamente ao "Boletim de Ariel" (revista biobibliográfica de que foi diretor). De acordo com o que ainda nos reporta Silva Melo (1959), a Gastão Cruls, ouvidor mordaz, não escapava frase alguma -era, quase sempre, o campeão nos torneios de "perspicácia"; e fazia das palavras esdrúxulas e daquelas perguntas absurdas material para pilhéria e interpretações "homéricas", como aquelas da "língua tátá" em que os amigos interpelavam a vítima, deixando-a numa situação flagrantemente embaraçosa. As viagens pelo Norte e Nordeste foram, por sua vez, cruciais ao delineamento do perfil do escritor Cruls. As anedotas, as lendas indígenas e caboclas, as particularidades européias, as rememorizações dos feitos do jovem Conde de Nassau deram a Cruls um estilo inédito, sui generis, não contemporâneo de seu tempo e, talvez, também por causa disso, seja explicável uma certa apatia da crítica frente a sua produção literária. Crítica e críticos à parte, fervilhavam em Gastão Cruls a caricatura austera e a caramunha graciosa. Era inventivo e aventureiro. Era um sonhador. E tinha um conceito muito particular sobre amizade. Seu espírito brincalhão, entretanto, não instavam ofensas, e nem a picardia maliciosa ou irônica acarretava qualquer "revolta ou aborrecimentos". Infelizmente, conforme nos noticia Silva Melo (1959), tanta "alegria pelo viver" (p. 376) veio-Ihe a ser freada. Durante dois anos, continua S. Melo, uma enfermidade entristeceu-Ihe a alma e 0 semblante, até esvanecer-se rumo a outros paraísos, que não a Amazônia e o Rio de Janeiro. Quando fora estudante de medicina (recorda 0 amigo Silva Melo) sofrera de uma neurastenia. Ironia do destino, ou não, a mesma enfermidade volta ao paciente tantos anos depois e com enorme gravidade. 0 mais irônico, de acordo com S. Melo, é que estava praticamente recuperado quando surge uma infecção das vias urinárias: era a sua sentença de morte, ditada por uma intervenção cirúrgica, executada sob um dos termos técnicos que tanto conhecia -"a uremia". Sem dúvida, uma lástima constrangedora do destino, que não lhe permitiu terminar Angra (que seria, segundo Silva Melo, um de seus melhores livros) e Glória, outro livro sobre a Amazônia. Mas, esse mesmo destino, de modo algum foi capaz de ofuscar o talento, a competência, o carisma e todos os demais primores que compõem a obra do artista Gastão Luis Cruls." (MAIA, 2005, p. 41-44). 0bs.: As informações sobre as páginas das obras citadas foram por nós retiradas por não fazerem parte do escopo deste trabalho. Para eventual interesse do leitor, remetemos à dissertação referenciada, onde constam todas as informações necessárias sobre as obras e as páginas aqui eliminadas.
} 
sátiros e ninfas em posições libidinosas pode remeter a determinadas épocas da história da arte. Porém, seria muito arriscado determinar que seja uma ou outra, pois, embora a riqueza de detalhes sobre a peça, a descrição não é suficiente para delimitar-lhe por completo suas formas, traços e curvas. A completude de qualquer imagem mental que se faça da forma da mobília que emoldura 0 espelho fica, em parte, por conta da imaginação do leitor num processo de inteiramento dedutivo. As palavras ali reunidas são suficientes para preparar o leitor para a natureza do caso insólito que logo ocorrerá. Como se a descrição da mobília estivesse a emoldurar a própria narrativa, de forma que direciona cuidadosamente 0 olhar para o seu foco.

A questão das cores presentes nas molduras e ambientações desse conto também é um ponto a ser ressaltado, visto que as cores constroem significados. Assim, temos que 0 espelho de Cruls tinha por base a cor verde, a qual já foi associada à própria Venus, deusa do amor e sensualidade, bem como às Ninfas, reafirmadas nas gravuras do móvel. Outra cor presente no mesmo espelho é o acobreado, ou bronze, cor quente e estimulante. Havia no quarto do casal um abat-jour cuja lâmpada era sempre trocada por cores diferentes. No ápice da narrativa, a luz é vermelha, de forma a envolver e influenciar a percepção (das personagens e, quiçá, do leitor) dos momentos de carícias ardentes até a inflamação dos sentidos que culmina em assassinato.

Como a história é narrada em primeira pessoa e tudo o que é contado passa pelo filtro de uma subjetividade personificada, é pertinente hesitar entre a sanidade/insanidade, o sentido da visão, que pode ter sido, no momento do ato trágico, estimulado a partir da iluminação peculiar do ambiente ou dos seres que porventura ficaram prisioneiros no espelho da cortesã no passado e conseguiram a liberdade na cama da esposa do narrador.

Nesse conto de Gastão Cruls, o efeito da presença espelho evolui gradativamente em seu campo de ação. Inicialmente, a presença do objeto provoca um desentendimento entre 0 casal devido à estética peculiar de sua moldura, nada conveniente para uma respeitável senhora casada de sua época. Isa, antes do espelho, tinha um comportamento calmo, no que diz respeito a não ser muito dada aos prazeres da carne. 0 que era esperado de uma mulher de sua posição social. No entanto, o espelho foi, inicialmente, para ela como fora o coelho para Alice no país das maravilhas. Era a isca que a tiraria de um mundo insípido para 0 fantástico mundo que se abriria a sua frente logo em breve. Até esse ponto da narrativa não houve de fato nada de efeito especular, apenas o choque de um objeto estranho no ambiente familiar. Na sequência, Isa, revestida de encantamento e, ainda, de pureza, chama o marido para apreciarem juntos a imagem do casal envolta em luz vermelha na tripla superfície. Nesse momento, o espelho os revela sob uma estética gótica, fantasmagórica e com os primeiros sinais de luxúria. A cena, que Ihes parece como de cinema, desperta um desejo ardente entre os dois.

- um hálito quente de excitação erótica,
que nos urtigava o corpo de tentações
diabólicas e enchia o cérebro de
visões incandescentes. Dir-se-ia que
daquelas folhas de vidro estanhado
se projetavam sobre a nossa cama
todas as cenas de abominação e
luxúria, todos os vícios e torpitudes
que nelas se haviam fixado durante 0
tempo em que tinham estado a serviço
da cortesã. Não só Isa mas a mim
também, contagiara o mesmo ardor
da carne eternamente insatisfeita,
dos lábios que não se dessedentam,
dos sentidos que não se atreguam.
0 sangue que nos raivava nas veias
pedia volúpias novas, requintes nunca
dantes experimentados e, assim, no
álcool e em outros estimulantes ainda
mais nocivos íamos buscar a sensação
que não nos dava a realidade. (lbidem,
p. 343).

Toda essa sucessão de fatos e, principalmente, a alteração da conduta de sua esposa inflama-Ihe 0 ciúme. Ela, que antes parecia indiferente ao charme masculino, o que conferia ao marido um sentimento de segurança quanto à fidelidade conjugal, agora se demonstrava voluptuosa. Nesse momento, ele deseja 
promover uma quebra no rumo que a história vem tomando, ao tentar convencê-la a desfazer-se do objeto. Porém, obtém como resposta que aquele objeto foi 0 que trouxe a alegria de viver.

Em seguida, 0 espelho apresenta mais uma função na narrativa: a de mostrar os outros presos aos movimentos do eu. 0 narrador deduz que as imagens de todos os amantes que a meretriz atendeu diante daquele espelho ficaram ali, de alguma forma, presas e estavam a influenciar o comportamento de sua mulher. Presume que sua mulher quando queima de desejo não é por ele, mas pela imagem especular que se prende aos seus movimentos, porém mostra os outros. Sua revolta culmina no momento de fúria em que flagra 0 outro no espelho rachado e despedaça 0 vidro para se desfazer da imagem assombrosa, mas esta se multiplica infinitamente em cada fragmento que vai ao chão, e com um pedaço do espelho partido fere mortalmente a sua esposa.

A fala em primeira pessoa desse conto permite uma desconfiança, por parte do leitor, de que se trate de um caso de loucura. Se o personagem principal for diagnosticado louco pela crítica psiquiátrica literária, a obra passaria a ser verossímil? Seria tudo isso devaneios de uma mente insana e não efeitos mágicos especulares? Seria o fantástico ali introduzido como uma roupagem para escamotear a loucura de uma persona socialmente dentro dos padrões do status quo? 0 "fato" é, como já afirmado mais acima, que a narrativa deixa abertura para ambas as possibilidades: alucinação ou almas prisioneiras do espelho que saíam para momentos de prazer.

\section{CONSIDERAÇÕES FINAIS}

Pela condução da análise do conto, procuramos demonstrar o papel necessário das coisas no universo narrativo. Cada coisa, em ou fora do seu lugar, cria numa história aquilo que sem ela não poderia ser, pois as personagens são apenas uma parte dela (na vida real - não importa o modo como definamos isso - também é assim). Substancialmente, cada enredo é tramado entre uma voz que comunica (o narrador), as personagens e as coisas que aí se juntam para formar uma unidade sintagmática, de linguagem como trabalho estético e ficcional. Contudo, entre os milhões de coisas que existem, 0 espelho é uma delas privilegiada por exatamente ser aquela, não única certamente (se nos restringirmos ao espelho como artefato, não como algo que espelhe), que exibe, duplica, triplica e replica a figura humana (além, claro, de tudo que se defronte com ele, mas tanto os outros animais quanto as outras coisas não se vêem). Desse modo, o primeiro problema do trabalho foi 0 de apontar a necessária trama das coisas na construção narrativa. Com isso posto, 0 segundo passo foi o de destacar, ligeiramente, o objeto, a coisa espelho como parte fundamental de diversos tipos de narrativa para daí chegar ao terceiro elemento que é a literatura fantástica como um tipo específico de narrativa que entra em choque com a realidade efetivada como normal, até onde podemos constatar a olho nu, seguindo mais uma vez Roas. Isso tudo articulado diretamente com o conto " 0 espelho", de Gastão Crus, procurando estabelecer um feedback entre aqueles pontos teórico-crítico certamente como orientação e guia, mas também como possibilidade forjada no próprio escopo do texto ficcional.

Como vimos assinalando, o espelho colocado numa narrativa cria uma dimensão que evoca a temática do duplo, tanto replicando mundos, quanto as imagens do eu. É próprio do discurso ficcional não propor nenhuma verdade, assim como também não pode ser acusado de falsidade. Contudo, por meio do fingimento, de algo que não existe, termina por repropor uma condição de verdade sobre as coisas do mundo de onde ele partiu. Desse modo, a presença do espelho seria outro da literatura dentro de si própria que está com 0 olho voltado, em seu plano narrativo, e visualizando de esguelha uma realidade que ela imagina autonomamente como outro, mas necessariamente que remete à primeira.

Nessa dimensão ficcional, a presença do espelho deixa evidente esse jogo. Nisso o conto de Cruls torna-se um objeto privilegiado para examinarmos a 
figura paradigmática (e enigmática) do espelho. Assim o narrador 0 descreve,

E foi assim que [...] que aquele espelho acabou por fazer parte da mobília do nosso quarto. Ou melhor, acabou por tomar o lugar de quase todos os outros moveis, pois que só ele, grande como era e com um jogo de três faces, para corpo inteiro, ocupava toda uma parede, não deixando espaço senão para a cama e as duas mesinhas de cabeceira. Posta de lado a prevenção com que a recebi, a peça era, sem dúvida, magnífica. Uma verdadeira obra de arte, como talvez não existissem duas iguais pelo mundo afora. Seu estilo não sei. Não sou forte em história da artes. E, talvez, não tivesse mesmo estilo algum. Seria antes a concepção de qualquer artista original e desejoso de corresponder aos caprichos de quem 0 encomendara. Sim, porque 0 mais razoável era que aquele espelho, de tão grandes proporções e acabamento tão rico, tivesse sido feito de encomenda. (Ibidem, p. 339).

A passagem indica um intrincado de aspectos que envolve a anatomia do espelho, a voluptuosidade de Isa - camuflada sob a "mania dos leilões" (ibidem, loc. cit.) -, as ponderações morais do maridonarrador - "não era móvel para gente séria"; " as figurinhas de sátiros e ninfas [...] algumas delas impavam de luxúria, desbragavam-se em posturas lascivas" (ibidem, loc. cit.) - e a história do espelho num passado pertencente a uma famosa, exuberante e astuta cortesã. Percebemos nesse entrecho as várias séries sígnicas que se entrelaçam na narrativa, resumidas em: 0 espelho e sua potência replicante, a volúpia e insaciedade de Isa, a censura e o moralismo (e posteriormente repressão e violência física) do narrador-marido. Todo o restante da narrativa decorre daí. 0 personagem-marido-narrador narra a alguém a desventura vivida, como em Grande sertão: veredas, de Guimarães Rosa, onde Riobaldo narra tudo como se contasse para algum ouvinte. E como ali só há a fala do narrador, já que o ouvinte se traveste na figura do leitor, praticamente o conto é todo em discurso direto, sendo indireto nas falas de Isa, que são, obviamente, expostas pelo marido-narrador. Com isso, temos 0 ponto de vista e o foco do narrador, embora por vezes passe 0 foco para a esposa em momentos cruciais de persuasão retórica em relação às tomadas de decisão sobre que coisas comprar para 0 ambiente em comum do casal, a condição financeira de Isa, e a teimosia dela em relação ao espelho. Esse foco momentaneamente cedido é necessário para justificar 0 final trágico da narrativa. Sendo 0 marido tomado por uma volúpia assassina - posto em prática quando 0 erótico é desviado pelos transcursos da moral -, e narrando a posteriori, a partir do ciúme das imagens de homens fixadas no espelho e multiplicadas em seus estilhaços, há duas possibilidades de concluirmos sobre seu preventivo medo do espelho comprado pela mulher: 0 saber moral e 0 seu medo do além de si e do outro ao agredi-lo em expor seu pânico pelo que gosta, mas não tem coragem de revelar. 0 espelho aí cumpre sua função neutra de simplesmente mostrar. Contudo, quanto mais em pedaços, mais exibe o seu poderio de conseguir, pelas imagens multiplicadas, 0 intento da personagem render-se ao destempero da consciência. Isso é demonstrado pelas investidas do narrador ao seu interlocutor sobre sua mulher, 0 espelho e a decência de um lar recatado. Como a decência é algo consciente, portanto singular e individual, mas também algo social, logo coletivo e impessoal, a sua atitude sóbria perde a linha e sai do eixo. Com o marido-narrador reside 0 medo e 0 horror do além de si e do aquém de sua mulher. Nesse descompasso a narrativa assume a hesitação fantástica, também mostrando que outros mundos habitam tanto o mesmo corpo do vai-e-vem cotidiano quanto da ferocidade fantasmagórica inexplicável do nosso desconhecido.

Mas, vejamos o que ele próprio, o narrador, diz de si mesmo em certo momento sobre seu recato em contraponto à audácia de Isa: 
E ela abria a boca num sorriso e voltava o rosto para um lado e outro, encantada com as três imagens que 0 espelho Ihe devolvia. E logo puxandome pelo braço, enquanto eu, arredio, tinha os olhos nas tais figurinhas de bronze, que, a um exame mais atento, ainda me pareciam mais despudoradas. [...] Vi-me junto dela que me tomava pela cintura, e os nossos lábios se procuraram para um longo beijo. (Ibidem, p. 342).

No trecho citado o desejo explicitado à flor da pele por meio da personagem Isa, sempre regulado pelo narrador, que sofre violentamente as consequências de uma sociedade pautada pela moral e ética do gozo incorpóreo, que é o único prazer plausível assegurado pelo mundo da cristandade ou os derivados dele.

Tudo isso é o preparativo para a introdução do elemento fantástico no conto em que do espelho as imagens antigas dos homens que frequentavam a casa da cortesã "saíssem" do espelho e passassem a dormir com Isa incorporadas ao narrador, manipulando o seu corpo, segundo o olhar do marido narrador, que os via de relance por um olhar fugidio para o espelho. Com essas fantasmagorias invadindo o quarto do casal; Isa cada vez mais entregue ao deleite do espelho; e o ciúme do marido chegando ao paroxismo, o final só poderia ser trágico: num rompante de fúria, ele despedaça o espelho e em cada pedaço vendo as imagens do infame, nos cacos de espelho, a zombar dele, termina por assassinar Isa com esse pedaço espelhado.

A reflexão fantástica do espelho, nesse caso, gerou luxúria, ciúme, paixão e morte, mas há outra, como, por exemplo, a da personagem de Machado de Assis, em que a imagem do alferes, gerada também por um antigo e majestoso espelho,

obra rica e magnífica, que destoava do resto da casa, cuja mobília era modesta e simples... Era um espelho que the dera a madrinha, e que esta herdara da mãe, que o comprara a uma das fidalgas vindas em $1808 \mathrm{com}$ a corte de D. João VI. Não sei o que havia nisso de verdade; era a tradição.
0 espelho estava naturalmente muito velho; mas via-se-lhe ainda 0 ouro, comido em parte pelo tempo, uns delfins esculpidos nos ângulos superiores da moldura, uns enfeites de madrepérola e outros caprichos do artista. Tudo velho, mas bom... (ASSIS, 2001, p. 405).

Duplicava não o desejo ardente da personagem, mas 0 de poder e glória, mesmo que pequena, mas glória.

Em "0 espelho" de Guimarães Rosa talvez contivesse a explicação necessária para o narrador de Gastão Cruls:

Fui num lavatório de edifício público, por acaso. Eu era moço, comigo contente, vaidoso. Descuidado, avistei [...] Explico-Ihe: dois espelhos - um de parede, 0 outro de porta lateral, aberta em ângulo propício - faziam jogo. E o que enxerguei, por instante, foi uma figura, perfil humano, desagradável ao derradeiro grau, repulsivo senão hediondo. Deu-me náusea, aquele homem, causava-me ódio e susto, eriçamento, espavor. E era - logo descobri... era eu, mesmo! 0 senhor acha que eu algum dia ia esquecer essa revelação? (R0SA, 2001, p. 96).

Embora não seja 0 objetivo deste trabalho abordar 0 espelho machadiano ou roseano, os trechos servem para demonstrar que a vida dos espelhos, registrada ficcionalmente, é muito agitada, dando a ver caleidoscopicamente tantas imagens quanto seja possível mirarmos: individual ou social; singular ou coletiva. 0 fato é que os espelhos estão presentes em cada recanto de nossas vidas, ficcional ou realmente. A vantagem para nós humanos de sua presença na ficção é a de sua denúncia como um ser que nos revela para além de nós mesmos, para o bem e para o mal. Ao deixar isso claro na ficção, os espelhos assumem uma clarividência sobre nós que normalmente desconhecemos, mas que é real. 0 problema disso é que normalmente tanto os espelhos quanto as outras coisas que aparecem nas ficções são encaradas como 
metáforas, alegorias ou, no pior dos casos, como

Recebido em: 01/10/2018

apólogos, assegurando que nós humanos além do senhor dos discursos também somos senhores sobre todas as coisas, inclusive de outros seres humanos vistos como coisas ao contrário do que seria ver as coisas como seres fundantes, conosco, de mundos, sejam eles quais forem.

\section{REFERÊNCIAS}

ASSIS, M. de. 0 espelho. In: ASSIS, M. de. Contos: uma antologia. Seleção, introdução e notas John Gledson. São Paulo: Companhia das Letras, 2001. Vol. I, p. 401410.

CRULS, G. 0 espelho. In: CRULS, G. Contos reunidos. Rio de Janeiro: José Olympio, 1951, p. 339-348.

ECO, U. Sobre espelhos e outros ensaios. Tradução Beatriz Borges. Rio de Janeiro: Nova Fronteira, 1989.

HEIDEGGER, M. A coisa. In: HEIDEGGER, M. Ensaios e conferências. 8. ed. Tradução Emmanuel Carneiro Leão. Petrópolis, RJ: Vozes, p. 143-160.

INGOLD, T. Trazendo as coisas de volta à vida: emaranhados criativos num mundo de materiais. Horizontes Antropológicos, Porto Alegre, v.18, n. 37, p. 25-44, jan./jun. 2012. Disponível em: $<$ http://www.scielo.br/scielo.php?script=sci_ arttext\&pid=S0104-71832012000100002>. Acesso em: 03 jan. 2016.

MAIA, C. S. Gastão Luis Cruls: uma nova recepção. 2005. Dissertação (Mestrado em Estudos Literários) Programa de Pós-Graduação em Estudos Literários, Universidade Estadual Paulista Júlio de Mesquita Filho, Araraquara, São Paulo, 2005. Disponível em: $<$ https://pt.scribd.com/document/38596057/Tesede-Mestrado> Acesso em 12/12/2016.

ROAS, D. A ameaça do fantástico: aproximações teóricas. Tradução Julián Fucks. São Paulo: Ed. da Unesp, 2014.

ROSA, G. 0 espelho. In: ROSA, G. Primeiras estórias. 15. ed. Rio de Janeiro: Nova Fronteira, 2001. 